\title{
DIASPORA MADURA: ANALISIS MODAL SOSIAL DALAM USAHA SEKTOR INFORMAL OLEH MIGRAN MADURA DI KECAMATAN TANAH SAREAL, KOTA BOGOR, JAWA BARAT
}

\author{
Diaspora Madura : Social Capital Analysis in The Business in Informal Sector of Madura \\ Migrants in Tanah Sareal Subdistrict, Bogor District, West Java
}

\author{
Yakob Arfin Tyas Sasongko*) dan Ekawati S. Wahyuni
}

Departemen Sains Komunikasi dan Pengembangan Masyarakat, Fakultas Ekologi Manusia, IPB

*)Email : yakobdanarfin@gmail.com

\begin{abstract}
Madurese is one of the ethnic groups in Indonesia which has a high level of mobility. The distinctive feature of their migration is affiliation patterned chained migration. In the destination area, Madurese migrants developed the bussines in informal sector, that is scrap trading business. Social capitals played a role in that bussines, so it grew among Madurese migrants only. Social capital consisted of networks, trust and norms. Madurese migrants network was narrow, but the most network nodes involved in the acquisition of raw materials and capital was work partner and Madurese migrants association. The trust level of Madurese migrants was low, because of the trust well done with Madurese only, while less with local society. The vital rules that must be obeyed by Madurese migrants in the bussines in informal sector was mutual respect among traders. It needed to prevent conflicts that could reduce the solidarity among Madurese migrants. But although the Madurese migrants had a limitation in terms of financial and human capital, their bussines still could grow and develop among Madurese migrant caused of social capital they had.
\end{abstract}

Keywords: chain migration, informal sector, madurese migrants, social capital

\begin{abstract}
ABSTRAK
Madura merupakan salah satu suku di Indonesia yang memiliki tingkat mobilitas yang tinggi. Ciri migrasi yang dilakukan orang madura yakni pola afiliasi saluran migrasi. Di tempat tujuan, Migran Madura mengembangkan usaha pada sektor informal, yakni usaha dagang barang bekas. Modal sosial berperan pada usaha tersebut, sehingga usaha tersebut berkembang hanya diantara migran madura. Modal sosial terdiri dari jaringan,kepercayaan dan norma. Jaringan sosial migran Madura tergolong sempit, namun simpul yang paling berperan dalam perolehan bahan baku dan modal adalah teman kerja dan perkumpulan migran Madura. Tingkat kepercayaan yang dimiliki migran Madura tergolong rendah, Hal ini dikarenakan kepercayaan yang dibangun baik hanya pada sesama migran Madura, sementara kepercayaan migran Madura terhadap masyarakat setempat tergolong rendah. Peraturan yang harus ditaati oleh sesama migran Madura dalam menjalankan usaha sektor informal adalah sikap saling menghargai usaha yang dimiliki oleh orang madura lainnya. Hal tersebut diperlukan untuk menghindari konflik yang dapat menurunkan solidaritas antar migran Madura. Namun walaupun migran Madura memilihi keterbatasan pada aspek keuangan dan modal manusia, usaha mereka tetap dapat tumbuh dan berkembang diantara sesama migran Madura dikarenakan modal sosial yang mereka miliki.
\end{abstract}

Kata kunci : migrasi berantai, migran madura, modal sosial, sektor informal

\section{PENDAHULUAN}

\section{Latar Belakang}

Migrasi penduduk antar wilayah di Indonesia telah lama terjadi. Perpindahan penduduk dari Jawa ke luar Jawa yang disponsori oleh pemerintah telah terjadi sejak Tahun 1905. Di samping itu, telah terdapat pula perpindahan penduduk dari beberapa suku di Indonesia, misalnya suku Minangkabau di Sumatra Barat dan suku Bugis di Sulawesi Selatan. Di samping itu terjadi pula perpindahan penduduk swakarsa. Arus migrasi penduduk makin meningkat setelah tersedianya prasarana transport (darat, laut maupun udara) yang baik, yang menghubungkan antar wilayah satu dengan yang lain (Mantra, 1992).

Fenomena migrasi yang dilakukan oleh orang Madura sudah berlangsung selama beberapa abad lalu. Sejak jaman penjajah masyarakat Madura sudah dikenal sebagai perantau (migran) ke berbagai provinsi di Indonesia (Warsono, 1992). Hampir sekitar 2,5 juta orang Madura yang dalam Tahun 1930 bertempat tinggal di Jawa Timur (De Jonge, 1989). Bagi orang Madura, meninggalkan tanah kelahirannya telah dilakukan sejak awal abad 19 terutama ke wilayah Jawa Timur (Suhanadji, 1998). Pola afiliasi menjadi ciri migrasi yang dilakukan oleh orang Madura, 
yakni melalui ikatan kekerabatan yang didukung oleh akses informasi dan ekonomi. Faktor geologis Pulau Madura yang kurang menguntungkan untuk mengembangkan usaha pertanian menjadi salah satu faktor kuat orang Madura bermigrasi ke daerah lain yang dianggap dapat meningkatkan taraf kehidupan ekonomi keluarga. Kondisi pulau Madura yang gersang dan kering menjadi pendukung timbulnya motif ekonomi untuk bermigrasi.

Dalam perkembangannya, migrasi orang Madura menunjukkan gejala yang bersifat kultural, bahwa migrasi sudah menjadi pola kebiasaan yang setiap hari terus mengalir melalui saluran (channel), famili, teman dekat, maupun kerabat sekampung (Suhanadji, 1998). Sebagai migran yang mendiami suatu daerah yang memiliki kebudayaan dan sumberdaya alam yang berbeda dengan daerah asalnya, migran Madura mengembangkan suatu strategi adaptasi untuk tetap bertahan hidup, yaitu adaptasi secara ekonomi maupun sosial. Strategi adaptasi ekonomi dikembangkan untuk dapat memperoleh akses ekonomi untuk meningkatkan taraf kehidupannya, sedangkan strategi adaptasi sosial dikembangkan untuk menjalin interaksi sosial yang harmonis dengan penduduk lokal.

Rendahnya kapital manusia yang ditunjukkan melalui tingkat pendidikan menjadi kendala mengapa sebagian besar orang Madura di Kota Bogor akses terhadap ekonomi hanya terbatas sebagai pedagang di sektor informal. Sektor informal menunjukkan sebagai sebuah kegiatan ekonomi berskala kecil. Keterbatasan migran Madura dalam hal keterampilan, pendidikan dan akses menyebabkan kesempatan untuk memasuki sektor formal pun terbatas. Dalam studi yang dilakukan Suhanadji (1998) menunjukkan upaya yang dilakukan oleh migran Madura untuk memasuki kegiatan ekonomi informal ialah dengan melakukan diversifikasi usaha dan memilih jenis pekerjaan yang sesuai dengan lingkungan hidupnya serta disesuaikan dengan potensi yang dimiliki. Artinya, dalam proses adaptasi tersebut orang Madura telah melakukan pengukuran terhadap kapasitas kemampuan yang dimiliki untuk mengembangkan ekonomi mana yang akan menjadi pekerjaannya. Dengan keterbatasan dalam hal pendidikan, migran Madura memperkirakan untuk memasuki sektor informal dan berusaha untuk menguasai berbagai bentuk usaha yang tercakup dalam sektor informal seperti pedagang sate, pedagang soto, tukang parkir, pengumpul besi tua dan sebagainya. Dalam hal ini, modal sosial yang mencakup nilai dan norma yang dimiliki oleh orang Madura menjadi sarana penting untuk mengembangkan kegiatan ekonomi tersebut (Ahmadi, 2003). Oleh karena itu penting untuk diketahui bagaimana modal sosial yang terjadi dalam sektor informal oleh migran Madura di daerah migrasi.

\section{Masalah Penelitian}

Orang Madura melakukan migrasi umumnya disebabkan oleh kondisi geografis Pulau Madura yang kurang mendukung untuk pengembangan kegiatan ekonomi. Kondisi tanah Pulau Madura yang bersifat basa oleh lapisan kapur mendorong penduduknya untuk bermigrasi karena kurang berpotensi untuk mengembangkan pertanian (Kuntowijoyo, 2002), namun dalam proses Migrasi tersebut orang Madura melakukan migrasi secara berantai melalui pola afiliasi kekerabatan dan kekeluargaan, sehingga masalah yang perlu diteliti adalah bagaimana proses migrasi berantai yang berlangsung dalam proses migrasi migran Madura ke Kota Bogor? Dalam hubungannya dengan kegiatan ekonomi yang dilakukan di daerah tujuan migrasi, migran Madura dikenal sebagai salah satu etnis yang menguasai sektor informal yang ciri utamanya dapat ditemukenali melalui jenis pekerjaan seperti pedagang besi tua, pedagang soto, pedagang sate, pengusaha meubel dan sebagainya. Untuk mendukung hal tersebut, perlu diketahui bagaimana sektor informal yang dikembangkan oleh migran Madura di Kota Bogor? Dalam kaitannya dengan usaha sektor informal tersebut perlu dianalisis bagaimana modal sosial pada usaha sektor informal yang dikembangkan oleh migran asal Madura di Kota Bogor?

\section{Tujuan Penelitian}

Tujuan yang ingin dicapai dalam penelitian ini adalah:

1. Mengidentifikasi proses migrasi berantai yang dilakukan oleh migran Madura ke Kota Bogor.

2. Menganalisis usaha sektor informal yang dikembangkan oleh migran Madura di Kota Bogor.

3. Menganalisis modal sosial dalam usaha di sektor informal oleh migran Madura di Kota Bogor.

\section{Kegunaan Penelitian}

Hasil penelitian ini diharapkan dapat berguna bagi berbagai pihak, diantaranya adalah:

1. Akademisi, penelitian ini diharapkan dapat menjadi referensi bagi peneliti yang ingin mengkaji lebih lanjut mengenai kajian migrasi, khususnya migrasi yang dilakukan orang Madura serta hubungannya dengan modal sosial dan strategi adaptasi.

2. Masyarakat, penelitian ini diharapkan dapat memberi dampak positif bagi masyarakat, khususnya untuk menambah pengetahuan tentang kajian migrasi orang Madura dalam kaitannya dengan penguasaan terhadap

3. sektor usaha informal

4. Pemerintah, penelitian ini dihaparkan dapat memberikan masukan atau dijadikan bahan pertimbangan bagi para pengambil kebijakan (pemerintah) dalam perencanaan, mengambil keputusan dan membuat kebijakan mengenai migrasi.

\section{PENDEKATAN TEORITIS}

\section{Definisi dan Jenis Migrasi}

Istilah umum bagi gerak penduduk dalam demografi adalah population mobility atau secara lebih khusus territorial mobility yang biasanya mengandung makna gerak spasial, fisik dan geografis (Shryllock dan Siegel, 1973 dalam Rusli 1996 hal 136). Ke dalamnya termasuk dimensi gerak penduduk permanen maupun dimensi non-permanen. Migrasi merupakan dimensi gerak penduduk permanen, sedangkan dimensi gerak penduduk non-permanen terdiri dari sirkulasi dan komutasi.

Rusli (1996) menyampaikan bahwa seseorang dikatakan melakukan migrasi apabila ia melakukan pindah tempat tinggal secara permanen atau relatif permanen (untuk jangka waktu minimal tertentu) dengan menempuh jarak minimal tertentu, atau pindah dari satu unit geografis ke unit geografis lainnya. Unit geografis sering berarti unit administratif pemerintahan baik berupa negara maupun 
bagian-bagian dari negara. Migrasi adalah suatu bentuk gerak penduduk geografis, spasial atau teritorial antara unitunit geografis yang melibatkan perubahan tempat tinggal yaitu tempat asal ke tempat tujuan. Orang yang melakukan migrasi disebut sebagai migran, karena itu seseorang yang disebut migran ada kemungkinan telah melakukan migrasi lebih dari satu kali. Secara umum migrasi ada dua jenis yaitu migrasi internal dan migrasi internasional. Dalam bentuk antarnegara, emigrasi (pelakunya emigran) adalah migrasi internasional dipandang dari negara asal atau negara pengirim, sementara imigrasi (pelakunya imigran) bilamana migrasi tersebut dilihat dari negara penerima atau negara tujuan. Selain itu terdapat juga istilah migrasi masuk neto, migrasi keluar neto dan migrasi semasa hidup. Migrasi masuk neto yaitu apabila di suatu daerah dalam wilayah suatu negara jumlah migrasi masuk lebih banyak dari pada migrasi keluar, demikian sebaliknya dengan migrasi keluar neto, sedangkan migrasi seumur hidup adalah orang yang ditemukan tinggal/berdomisili di luat tempat kelahirannya.

\section{Teori Dorong-Tarik (Push-Pull Theory)}

Menurut Lee (1984), faktor-faktor yang mempengaruhi orang mengambil keputusan untuk bermigrasi dan proses migrasi, dapat disingkat menjadi empat pokok, yaitu: (1) Faktor-faktor yang terdapat di daerah asal, (2) Faktor-faktor yang terdapat di tempat tujuan, (3) Penghalang antara, dan (4) Faktor-faktor pribadi.

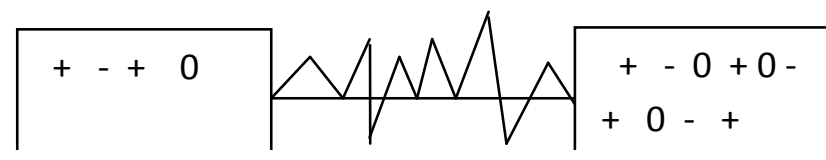

Daerah asal

Penghalang antara

Daerah tujuan

Gambar 1. Faktor Tempat / Daerah Asal dan Tempat / Daerah Tujuan, serta Penghalang Antara dalam Migrasi.

Pada setiap daerah banyak faktor yang mempengaruhi orang untuk menetap atau menarik orang untuk pindah ke daerah tersebut, serta ada pula faktor-faktor lain yang memaksa orang untuk meninggalkan daerah itu. Faktorfaktor tersebut dalam bentuk diagram serta memberikan simbol + (plus) dan - (minus) untuk memaknai faktorfaktor tersebut. Faktor-faktor + dan - terdapat baik di tempat asal maupun di tempat tujuan. Selain itu faktorfaktor lain ditunjukkan dengan tanda 0 yang pada dasarnya tidak ada pengaruhnya sama sekali terhadap penduduk.

\section{Faktor Pendorong Orang Madura Bermigrasi}

Faktor iklim dan geologis pulau Madura menjadi pendorong migrasi orang Madura. Kuntowijoyo (2002) memberikan penjelasan yang rinci mengenai kondisi dasar ekologis Pulau Madura, dilihat dari aspek tanah dan iklim, persediaan air, serta keberadaan hutan yang hampir musnah. Madura kekurangan tanah vulkanis. Wilayah kapur bagian utara, tanahnya merupakan campuran dari pasir kuarsa dan mineral lainnya, sehingga mudah digerogoti erosi oleh air selama musim penghujan dan oleh angin selama musim kemarau. Sedikitnya tanah pertanian, dalam luas dan kualitas, selalu menjadi ciri utama yang menonjol dari perekonomian di Madura. Respon orang Madura terhadap kekurangan ekologis ini penting untuk dicatat.
Orang Madura tidak hanya memiliki persediaan tanah yang sedikit, namun kenyataannya mereka juga kekurangan tenaga pengolah tanah.

Selain faktor iklim dan geologis, tidak adanya hambatan baik secara psikologi, sosial dan budaya serta beragamnya pekerjaan yang tersedia di daerah tujuan dan didukung cerita sukses yang dibawa orang-orang Madura ketika pulang kampung, tersedianya lapangan kerja yang lebih luas dan bervariasi terutama pada pekerjaan sektor informal serta tersedianya sarana transportasi yang memadai juga menjadi pendorong dan penarik bagi orang Madura untuk mengambil keputusan bermigrasi (Suhanadji, 1998). Menurut Noer (2008), selain motif ekonomi, dalam kasus migrasi individual perempuan di Bekasi didorong oleh faktor status perkawinan.

\section{Diaspora Madura}

Istilah diaspora (bahasa Yunani kuno, "penyebaran atau penaburan benih") digunakan (tanpa huruf besar) untuk merujuk kepada bangsa atau penduduk etnis manapun yang terpaksa atau terdorong untuk meninggalkan tanah air etnis tradisional mereka; penyebaran mereka di berbagai bagian lain dunia, dan perkembangan yang dihasilkan karena penyebaran dan budaya mereka.

Diaspora Madura identik dengan budaya yang melekat pada orang Madura sebagai migran, yakni bagaimana mempertahankan eksistensinya di antara etnis lainnya serta bagaimana orang lain yang berinteraksi dengan mereka dapat memahami dan memaknai keberadaannya sebagai etnis Madura. Salah satu upaya yang dilakukan untuk menunjukkan identitas Madura adalah dengan tinggal bersama membentuk suatu komunitas serta secara tidak langsung membudayakan pekerjaan yang seragam, sehingga pekerjaan yang dikembangkan oleh orang Madura tidak hanya sebagai mata pencaharian, tetapi juga menjadi identitas atau simbol sebagai etnis Madura. Keberadaan orang Madura di Kota Bogor yang dikaji dalam penelitian ini merupakan salah satu bentuk diaspora yang dimaksud dalam definisi diaspora Madura.

\section{Konsep Modal Sosial}

Konsep modal sosial muncul sebagai respons dari kondisi meregangnya hubungan antar manusia dan semakin munculnya ketidakpedulian terhadap sesama manusia. Konsep modal sosial sangat beragam dan umumnya dirumuskan berdasarkan kasus-kasus tertentu dimana modal sosial menjadi salah satu faktor pendukung kemajuan ekonomi (Ahmadi, 2003). Putnam (1993) mendefinisikan modal sosial dengan mengacu pada "ciri-ciri organisasi sosial, seperti jaringan sosial (social network), normanorma (norms), dan kepercayaan (trust) yang memfasilitasi koordinasi untuk sesuatu yang manfaatnya bisa dirasakan bersama-sama (mutual benefit). Modal sosial juga dipandang sebagai hubungan horizontal di antara orangperorang berdasarkan pada jaringan sosial dan norma yang ada (Putnam 1995).

Coleman (1988) mendefinisikan modal sosial dari sudut pandang fungsi modal sosial itu sendiri yang menekankan pada struktur sosial. Ia menyebutkan bahwa fungsi yang dapat diidentifikasikan dari modal sosial adalah nilai dari aspek-aspek struktur sosial untuk memanfaatkan sumberdaya yang ada untuk mencapai tujuan anggota- 
anggotanya. Aspek-aspek struktur sosial yang dimaksud dalam definisi tersebut menunjuk pada sekumpulan kewajiban dan harapan, jaringan informasi, norma-norma dan sanksi-sanksi yang efektif yang dapat memaksa atau menyemangati seseorang untuk bertigkah laku agar tetap eksis dalam menjaga hubungan dengan orang lain. Selain Putnam dan Coleman, Fukuyama (1999) juga menyebutkan bahwa modal sosial menunjuk pada seperangkat sumber daya yang melekat dalam hubungan dan dalam organisasi sosial komunitas serta sangat berguna bagi pengembangan kognitif dan sosial anak.

Secara umum modal sosial mencakup tiga unsur utama seperti yang telah dikemukakan oleh Putnam (1993) yaitu kepercayaan, jaringan, dan norma. Unsur-unsur tersebut dapat digunakan untuk melihat keberadaan modal sosial dalam suatu kelompok masyarakat.

Secara umum modal sosial mencakup tiga unsur utama seperti yang telah dikemukakan oleh Putnam (1993) yaitu kepercayaan, jaringan, dan norma. Unsur-unsur tersebut dapat digunakan untuk melihat keberadaan modal sosial dalam suatu kelompok masyarakat.

\section{a. Kepercayaan}

Merujuk pada tulisan Lawang (2005), definisi trust dalam bahasa Inggris merupakan bentuk kata benda dan kata kerja. Kepercayaan, keyakinan dan juga rasa percaya adalah makna trust sebagai kata benda, sedangkan sebagai kata kerja trust berarti sebagai sebuah proses mempercayai sesuatu yang jelas sasarannya. Dalam tulisannya Lawang juga menyatakan bahwa di dalam kepercayaan antar manusia terdapat tiga hal penting yang saling terkait, yaitu: (i) Hubungan sosial, (ii) Harapan, dan (iii) Tindakan sosial atau interaksi sosial. Berdasarkan tiga hal mendasar tersebut kepercayaan yang dimaksud menunjukkan pada hubungan antara dua pihak atau lebih yang mengandung harapan yang menguntungkan salah satu atau kedua belah pihak melalui interaksi sosial. Sebagai konstruksi sosial historis empirik, kepercayaan tidak dapat terbentuk melalui proses satu kali, melainkan dibangun atas pengalaman, akumulatif, harapan yang teruji, penghargaan dan keuntungan yang terbangun di dalamnya, oleh karena itu diperlukan proses untuk membangun kepercayaan secara terus menerus.

\section{b. Jaringan}

Menurut Lawang (2005), jaringan merupakan terjemahan dari kata network. Pada dasarnya jaring berhubungan satu sama lain melalui simpul-simpul (ikatan). Jaring (net) apabila ditambah dengan kerja (work) memunculkan arti "kerja" (bekerja) dalam hubungan antar simpul-simpul seperti halnya jaring (net). Dalam teori modal sosial, arti jaringan dapat dijelaskan berdasarkan empat hal:

1. Ada ikatan antar simpul (orang atau kelompok) yang dihubungkan dengan media (hubungan sosial). Hubungan sosial tersebut diikat oleh kepercayaan, dan kepercayaan itu dipertahankan oleh norma yang mengikat kedua belah pihak.

2. Ada kerja antar simpul (orang atau kelompok) yang melalui hubungan sosial dapat membentuk suatu kerjasama (bukan kerja bersama-sama).

3. Dalam kerja jaring (jaringan) tersebut terdapat ikatan (simpul) yang tidak dapat berdiri sendiri. Apabila salah satu simpul terputus, maka seluruh jaring tidak dapat berfungsi. Seluruh simpul menjadi satu kesatuan dan ikatan yang kuat serta antara orang-orang dan hubungannya tidak dapat dipisahkan.

4. Ikatan atau pengikat (simpul) dalam modal sosial adalah norma. Norma tersebut mengatur dan menjaga bagaimana ikatan dan medianya tetap terpelihara dan dipertahankan.

\section{c. Norma}

Norma muncul dari pertukaran yang saling menguntungkan (Fukuyama, 1999; Blau 1963 dalam Lawang, 2005). Homans (1974) dalam Lawang (2005) menjelaskan pengertian tersebut, apabila dalam pertukaran tersebut keuntungan hanya dinikmati oleh satu pihak saja, pertukaran sosial selanjutnya tidak akan terjadi. Karena norma yang muncul bukan sekali jadi melalui satu pertukaran saja. Apabila dalam pertukaran pertama keduanya saling menguntungkan, maka akan muncul pertukaran yang kedua dengan harapan akan memperoleh keuntungan. Dalam tulisannya Lawang juga menjelaskan bahwa norma bersifat resiprokal. Pengertian resiprokal adalah bahwa isi dari norma tersebut menyangkut hak dan kewajibankedua belah pihak yang dapat menjamin keuntungan yang diperoleh dari suatu kegiatan tertentu. Dalam hal ini, orang yang melanggar norma akan berdampak pada berkurangnya keuntungan kedua belah pihak dan terdapat sanksi negatif yang keras.

\section{Konsep Sektor Informal}

Konsep sektor informal pertama kali digagas oleh Hart melalui tulisannya yang diterbitkan pada Tahun 1973, seorang antropolog Inggris yang mengamati kegiatan ekonomi penduduk di Ghana, yang kemudian konsep tersebut dikembangkan dan diterapkan oleh ILO dalam penelitian di delapan kota di Dunia Ketiga, salah satunya Jakarta. Dalam pengamatannya yang berfokus pada kegiatan penduduk di Kota Accra dan Nima, Ghana, menunjukkan bahwa kesempatan memperoleh penghasilan di kota dapat dibagi dalam tiga kelompok, yaitu formal, informal sah dan informal tidak sah. Masing-masing kelompok itu dibedakan dalam berbagai kategori yang didasarkan pada kegiatan yang dilakukan individu, jumlah pendapatan dan pengeluaran yang mengalir dalam perekonomian kota. Pembedaan sektor formal dan informal dilihat dari keteraturan cara kerja, hubungan dengan perusahaan, curahan waktu serta status hukum yang dilakukan. Sethuraman (1996) menyebutkan bahwa istilah sektor informal biasanya digunakan untuk menunjukan sejumlah kegiatan ekonomi yang berskala kecil. Sektor informal merupakan manifestasi dari situasi pertumbuhan kesempatan kerja di negara sedang berkembang, karena mereka yang memasuki kegiatan berskala kecil ini di kota bertujuan untuk mencari kesempatan kerja dan pendapatan daripada memperoleh keuntungan.

\section{Kerangka Pemikiran}

Modal sosial merupakan modal yang perlu dimiliki oleh pelaku usaha yang memiliki keterbatasan dalam hal modal finansial dan modal manusia. Modal sosial memiliki tiga pilar utama yaitu jaringan, kepercayaan dan norma. Sebagai migran yang bermigrasi ke Kota Bogor, migran Madura 
identik dengan pengembangan usaha di sektor informal. Dengan keterbatasannya dalam hal modal finansial dan modal manusia, modal sosial yang dimiliki oleh migran Madura berperan terhadap usaha yang dijalankan. Dalam kegiatan perdagangan atau usaha di sektor informal, migran Madura perlu mambangun jaringan sosial. Jaringan tersebut dapat dilihat dari segi kuantitas (jumlah) maupun jenis jaringannya (simpul). Jaringan sosial yang dimiliki dapat berpengaruh terhadap kemajuan usaha di sektor informal. Selain itu, migran Madura juga perlu membangun kepercayaan baik dengan sesama migran Madura maupun dengan masyarakat setempat (lokal Bogor).

Usaha yang dijalankan dapat bertahan dan berlangsung terus menerus apabila kepercayaan sosial ini dapat terpelihara dengan baik. Interaksi yang berlangsung dalam lingkup migran Madura mendorong terbentuknya aturan kerja di antara sesama migran Madura yang mengembangkan usaha di sektor informal. Ketaatan terhadap aturan yang disepakati dapat mewujudkan persaingan usaha yang sehat di antara sesama migran Madura.

Modal sosial berpengaruh terhadap keberlanjutan dan kemajuan usaha yang dikembangkan oleh migran Madura di sektor informal. Selain itu, kemajuan dalam usaha sektor informal dapat ditilik berdasarkan dua hal, yaitu kemampuan migran Madura dalam memanfaatkan simpul jaringan dan karakteristik migran, dalam hal ini karakteristik tersebut yaitu status perkawinan.

\section{Modal Sosial}

1. Jaringan

- Jumlah orang yang dikenal

- Simpul

2. Kepercayaan

- Terhadap sesama migran Madura

- Terhadan masvarakat setemnat

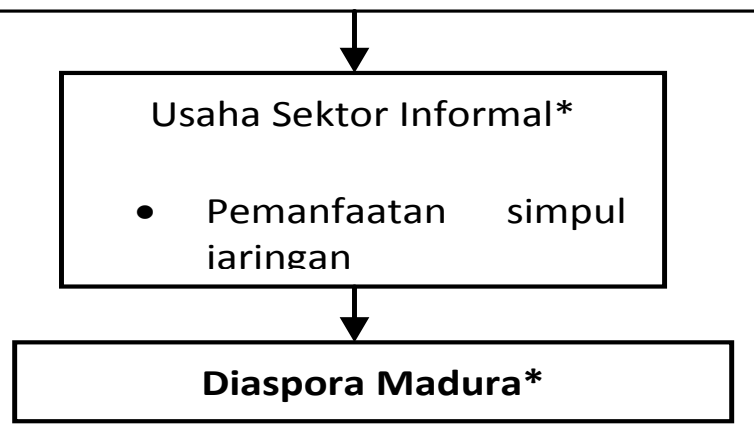

Gambar 2. Kerangka Pemikiran

$$
\begin{aligned}
\text { Keterangan }: \longrightarrow & : \text { berhubungan } \\
& * \text { : diukur secara kualitatif }
\end{aligned}
$$

Wujud usaha sektor informal yang dikembangkan oleh migran Madura serta keberadaannya yang terus bertahan dan semakin berkembang di Kota Bogor mencerminkan bentuk diaspora Madura. Selain didukung oleh hubungan kekerabatan yang kuat di antara sesama migran Madura, diaspora Madura juga dicirikan melalui kemampuan migran Madura dalam menemukan dan memanfaatkan peluang yang ada di daerah tujuan migrasinya.

\section{PENDEKATAN LAPANGAN}

\section{Lokasi dan Waktu Penelitian}

Penelitian ini dilaksanakan di Kecamatan Tanah Sareal, Kota Bogor, Provinsi Jawa Barat. Lokasi ini dipilih karena di kecamatan ini terdapat sejumlah migran Madura yang mengembangkan usaha di sektor informal. Pemilihan lokasi dilakukan secara sengaja (purposive) sesuai dengan kebutuhan penelitian. Studi lapangan dilaksanakan pada bulan April sampai dengan Juli 2012.

\section{Teknik Pengumpulan Data}

Jenis data yang digunakan dalam penelitian ini adalah data primer dan sekunder. Metode yang dipakai dalam penelitian ini adalah menggunakan kuesioner, wawancara, observasi dan dokumentasi. Pendekatan yang dilakukan dalam penelitian ini adalah pendekatan kuantitatif dengan didukung oleh data kualitatif untuk memperkaya data dan memahami fenomena sosial.

\section{Teknik Pengambilan Sampel}

Populasi dalam penelitian ini adalah migran Madura yang ada di Kecamatan Tanah Sareal, Kota Bogor, Provinsi Jawa Barat, sedangkan populasi sasaran penelitian ini adalah migran Madura yang mengembangkan usaha di sektor informal di Kecamatan Tanah Sareal, Kota Bogor. Unit analisis dalam penelitian ini adalah individu. Pemilihan responden dilakukan dengan metode purposive sampling. Seseorang diambil sebagai sampel karena peneliti menganggap bahwa seseorang memiliki informasi yang diperlukan bagi penelitian (Holmes et al. 2005). Dalam penelitian ini karakteristik pelaku usaha di sektor informal yang diteliti adalah: migran yang berasal dari Madura yang mengembangkan usaha di sektor informal di Kecamatan Tanah Sareal, Kota Bogor. Penelitian ini tercakup di tiga kelurahan yaitu Kelurahan Kayu Manis, Kelurahan Cibadak dan Kelurahan Kedung Badak. Untuk memperoleh responden migran Madura yang bekerja di sektor informal, peneliti memulai dari Kelurahan Kayu Manis dengan cara bertanya kepada pemilik warung makan di sekitar Jalan Raya Kayu Manis mengenai lokasi lapak usaha orang Madura. Dalam proses identifikasi tersebut peneliti ditunjukkan pada sebuah lapak usaha migran Madura yang berada di samping Hotel Bambu. Dari responden pertama tersebut peneliti diarahkan untuk menyusuri sepanjang Jalan Raya Kayu Manis dan Jalan Baru. Dari hasil penyusuran di sepanjang jalan tersebut dan petunjuk yang diperoleh dari responden pertama, peneliti memperoleh 30 responden yang tersebar di tiga kelurahan.

Dalam penelitian ini tercakup responden laki-laki dan responden perempuan. Responden laki-laki merupakan pelaku utama usaha di sektor informal yang dikembangkan oleh migran Madura. Pelaku utama yang dimaksud adalah orang yang menggagas kegiatan usaha di sektor informal. Responden perempuan bukan penggagas utama kegiatan usaha di sektor informal (kecuali yang berstatus janda), namun dalam kegiatan usaha tersebut responden perempuan berperan dalam usaha yang dijalankan oleh suaminya. Dalam hal ini peran tersebut didukung oleh pengetahuan responden perempuan mengenai hal-hal terkait usaha di sektor informal, di antaranya adalah: (1) Proses perolehan 
bahan baku yang sebagian besar diperoleh dari proyek bongkaran, (2) Informan yang memberi tahu kegiatan proyek bongkaran, dan (3) Periode berlangsungnya kegiatan bongkaran yang diikuti oleh suami. Dengan pengetahuan tersebut, responden perempuan dianggap memiliki peran yang cukup penting sehingga dapat memberikan informasi mengenai usaha sektor informal yang menjadi pekerjaan migran Madura di Kota Bogor.

\section{Teknik Pengolahan dan Analisis Data}

Data kuantitatif yang diperoleh melalui kuesioner diolah dengan menggunakan komputer. Selain pertanyaan yang bersifat kuantitatif, pada kuesioner juga terdapat pertanyaan kualitatif, oleh karena itu di dalamnya disajikan dalam bentuk pertanyaan terbuka dan pertanyaan tertutup. Pertanyaan terbuka ditujukan untuk memperoleh data kualitatif.

Data yang diolah merupakan data yang diturunkan dari kuesioner. Variabel yang diolah adalah variabel jaringan sosial dan variabel tingkat kepercayaan. Variabel jaringan sosial mengandung data mengenai jumlah orang yang dikenal dan jumlah simpul yang dimiliki oleh migran Madura di sektor informal. Jumlah orang yang dikenal oleh migran Madura bervariasi, oleh karena itu penulis mengklasifikasikan data tersebut berdasarkan ukuran jaringan (luas dan sempit), sedangkan data simpul jaringan diidentifikasi menurut perananannya. Pada variabel tingkat kepercayaan mengandung data tingkat kepercayaan terhadap sesama migran Madura dan tingkat kepercayaan terhadap masyarakat sekitar. Jumlah pertanyaan mengenai kepercayaan terhadap sesama migran Madura sebanyak tiga pertanyaan dan kepercayaan terhadap masyarakat setempat sebanyak enam pertanyaan. Setiap pertanyaan diberi skor dan hasilnya disajikan dalam bentuk tabel frekuensi. Data tersebut kemudian diinterpretasikan dan ditarik kesimpulan berdasarkan hipotesis yang ada, sedangkan data kualitatif disajikan dalam bentuk naratif dalam teks dan kutipankutipan langsung dari beberapa pernyataan responden. Selain mengenai jaringan sosial dan tingkat kepercayaan, di dalam kuesioner juga terdapat sejumlah pertanyaan yang tujuannya untuk mengidentifikasi informasi penting lainnya seperti riwayat migrasi, karakteristik responden serta mengidentifikasi kegiatan usaha di sektor informal.

\section{GAMBARAN UMUM LOKASI PENELITIAN DAN KARAKTERISTIK MIGRAN MADURA}

\section{Lokasi Migran Madura di Kota Bogor}

Kota Bogor merupakan salah satu kota di Provinsi Jawa Barat yang terletak 54 kilometer sebelah selatan Jakarta. Secara geografis Kota Bogor terletak di antara 106' 48' BT dan 6' 26' LS, dengan Luas Wilayah Kota Bogor sebesar $11.850 \mathrm{Ha}$ terdiri dari 6 kecamatan dan 68 kelurahan Dengan kedudukan geografis berada di tengah-tengah wilayah Kabupaten Bogor serta lokasinya yang dekat dengan Ibukota Negara, merupakan potensi yang strategis bagi perkembangan dan pertumbuhan ekonomi dan jasa, pusat kegiatan nasional untuk industri, perdagangan, transportasi, komunikasi, dan pariwisata (Pemerintah Kota Bogor 2011).

Berdasarkan renstra Pemerintah Kota Kota Bogor (2011), dalam Perda No 1 Tahun 2000 tercantum tentang Rencana Tata Ruang Wilayah (Tahun 1999-2009) yang menjelaskan bahwa fungsi Kota Bogor adalah: (1) Sebagai kota perdagangan, (2) Sebagai kota industri, (3) Sebagai kota permukiman, (4) Wisata ilmiah, dan (5) Kota pendidikan. Hal ini menarik orang untuk datang ke Kota Bogor dengan berbagai alasan, salah satunya adalah untuk memperoleh kesempatan kerja. Keadaan ini mengindikasikan sejumlah migran dari berbagai daerah berdatangan ke Kota Bogor untuk memanfaatkan peluang ekonomi Kota Bogor yang semakin berkembang.

Salah satu etnis yang bermigrasi ke Kota Bogor adalah migran etnis Madura. Dalam penelitian ini penulis mengkaji mengenai migran Madura yang memanfaatkan peluang ekonomi di sektor informal. Untuk memperoleh data dan informasi mengenai keberadaan migran Madura yang bekerja di sektor informal, penelitian ini dilaksanakan di Kecamatan Tanah Sareal, Kota Bogor, Jawa Barat yaitu di Keluarahan Kayu Manis, Kelurahan Cibadak dan Kelurahan Kedung Badak. Kawasan Jalan Baru yang terletak di Kelurahan Cibadak merupakan salah satu kawasan usaha migran Madura untuk menjalankan usahanya.

\section{Ciri-Ciri Migran Madura Dalam Usaha Sektor Informal}

Keberadaan migran Madura di kecamatan ini dapat dikenali dari jenis usahanya, yaitu usaha dagang barang bekas dan penyedia bahan bangunan. Jenis usaha yang digeluti mencerminkan bentuk tempat usahanya yang khas. Salah satu ciri khas yang memudahkan dalam menemukan orang Madura yaitu lapak usahanya yang sederhana, dan peletakan barang-barang bekas yang kurang tertata rapi. Berbeda dengan lapak usaha migran yang berasal dari daerah lain yang bentuk bangunannya relatif permanen, lapak yang dimiliki migran Madura dibangun secara sederhana dengan komposisi berupa seng dan kayu yang disusun membentuk seperti gudang. Di lapak tersebut terdapat sejumlah barang bekas yang merupakan komoditas usahanya seperti pagar bekas, teralis, kayu dan berbagai barang lain yang mencirikan sebagai barang yang tidak terpakai. Contoh lapak usaha migran Madura dapat dilihat dalam lampiran.

\section{Karakteristik Migran Madura}

Migran Madura yang melakukan migrasi ke Bogor dominan migran laki-laki, hal ini terkait dengan pekerjaan dan usaha yang dikembangkan untuk melangsungkan hidup, yakni pada usaha di sektor informal perdagangan. Berdasarkan usia, pada saat meninggalkan Madura jumlah paling tinggi yaitu pada usia 20-29 tahun, sedangkan pada saat penelitian dilaksanakan jumlah responden terbanyak pada usia 30-40 tahun. Goldscheider (1985) menyampaikan bahwa proporsi kaum muda pada umumnya lebih mobil daripada orang tua. Tingkat mobilitas kaum muda yang lebih tinggi mencerminkan dua skiklus hidup. Prosesproses yang berkaitan dengan umur yakni: (1) perkawinan dan pembentukan keluarga, dan (2) mobilitas karir dan pekerjaan. Dalam penelitian Warsono (1992), masyarakat Madura pada umumnya bermigrasi pada usia muda antara usia 12 tahun sampai 15 tahun. Bagi masyarakat Madura, rentang usia tersebut merupakan masa produktif untuk bekerja untuk mendukung ekonomi keluarga. Dilihat berdasarkan latar belakang pendidikan, jumlah terbanyak berlatar belakang pendidikan agama informal dengan jumlah sepuluh responden, sementara itu berdasarkan status perkawinannya, diketahui migran yang menjadi 
responden penelitian ini berstatus menikah, hanya satu responden saja yang berstatus janda. Berdasarkan asal daerah asalnya, migran Madura yang berusaha di sektor informal ini sebanyak 23 responden berasal dari Kabupaten Sampang.

\section{PROSES MIGRASI ORANG MADURA}

\section{Migrasi Berantai Migran Madura}

Etnis Madura dikenal sebagai salah satu etnis yang memiliki budaya migrasi, selain etnis Bugis, Batak dan Minangkabau (Mantra 1992). Terdapat sejumlah faktor yang mendorong masyarakat Madura untuk berpindah meninggalkan Pulau Madura menuju kota-kota di Pulau Jawa maupun luar Pulau Jawa. Seperti telah dikemukakan pada bagian awal, salah satu faktor kuat yang mendorong masyarakat Madura untuk bermigrasi adalah keadaan Pulau Madura yang kurang mendukung untuk meningkatkan ekonomi akibat sifat geografis Pulau Madura yang kering dan gersang.

Migrasi berantai yang dilakukan oleh masyarakat Madura berpola afiliasi yang berbasiskan pada hubungan keluarga, pertemanan dan pertetangggaan. Dalam proses migrasi tersebut, orang Madura berangkat ke Bogor bersama dengan saudara atau temannya dan bertempat tinggal bersama orang yang mengajak bermigrasi. Dalam waktu kurang lebih satu sampai dengan dua tahun bertempat tinggal di rumah kerabatnya yang di Bogor, mereka tidak hanya menumpang tempat tinggal, tetapi juga ikut bekerja membantu pekerjaan yang dimiliki oleh kerabatnya, sehingga dari pekerjaan tersebut mereka memperoleh keterampilan dalam usaha di sektor informal. Apabila keterampilan yang dimiliki sudah cukup memadai, maka mereka membuka usaha sendiri dalam jenis usaha yang sama.

Selama di Bogor, migran Madura sering pulang ke Madura, khususnya ketika lebaran atau ada acara yang diselenggarakan di Madura. Hal ini merupakan kesempatan untuk menceritakan keberadaan mereka selama di Bogor kepada kerabatnya yang ada di Madura, sehingga cerita tersebut menarik orang Madura lainnya untuk ikut bermigrasi ke Kota Bogor. Gambar 3 merupakan proses migrasi orang Madura ke Kota Bogor.

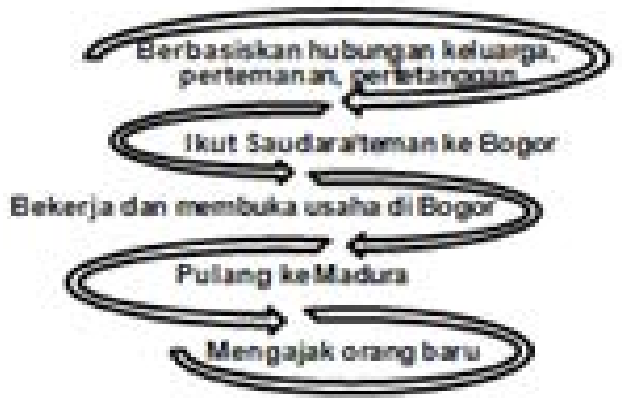

Gambar 3 Prent Migai Orani Madera ke Kot Boped

Bapak Ahmad (44 tahun) merupakan migran Madura asal Sampang, Kecamatan Kedundung dari Desa Daleman, yang membuka usaha dagang besi dan kayu bekas di Jalan
Raya Kayu Manis, Kecamatan Tanah Sareal. Pada saat lebaran ia pulang ke Madura. Pada kesempatan itulah ia menceritakan keberadaannya selama di Bogor kepada sanak saudaranya yang tinggal di Madura.

Budaya pulang kampung ini biasa disebut dengan istilah toron. Saat kembali ke Bogor, Bapak Ahmad mengajak saudara sepupunya yakni Ibu Fitri (33 tahun) dan Bapak Taufik (34 tahun). Pada masa itu ia mulai memainkan fungsi sosial dan fungsi ekonomi, yakni dengan memberikan tumpangan tempat tinggal kepada kedua sepupunya tersebut. Selama tinggal di rumah Bapak Ahmad, Ibu Fitri dan Bapak Taufik ikut membantu usaha yang dikembangkan oleh saudara sepupunya tersebut, yakni merakit besi yang sudah dilas menjadi rak.

Setelah tinggal dua tahun di rumah Bapak Ahmad, Ibu Fitri mulai mandiri secara keterampilan dan mulai menyewa tempat tinggal sendiri, demikian juga dengan Bapak Taufik. Bekal ilmu membuat rak yang ia pelajari selama kurang lebih dua tahun tersebut menjadi modal untuk ia membuka usaha yang sama.

\section{Usaha Sektor Informal Migran Madura di Kota Bogor}

\section{Jenis Usaha}

Usaha yang digeluti oleh migran Madura di Kota Bogor mencirikan hal yang berbeda dengan migran dari etnis lain. Usaha di sektor informal yang dikembangkan oleh migran Madura adalah usaha dagang barang bekas dan pemenuhan kebutuhan bahan bangunan. Jenis usaha tersebut meliputi dagang besi bekas, dagang kayu bekas, rak, dan juga gipsum. Migran Madura mampu melihat peluang usaha yang mungkin tidak terlintas menjadi sumber nafkah bagi masyarakat lain.

Hal yang dipandang tidak berguna oleh orang lain justru menjadi sumber nafkah bagi migran Madura. Bergerak dalam usaha dagang barang bekas merupakan pekerjaan utama sebagian besar orang Madura yang menjadi responden dalam penelitian ini. Data yang menunjukkan jumlah responden berdasarkan jenis usaha ditampilkan dalam Tabel 1.

Tabel 1. Jumlah dan Persentase Responden menurut Jenis Usaha, Kecamatan Tanah Sareal, Kota Bogor 2012

\begin{tabular}{lrr}
\hline \multirow{2}{*}{ Jenis Usaha } & \multicolumn{3}{c}{ Jumlah Orang } \\
\cline { 2 - 3 } & $\mathrm{N}$ & \multicolumn{2}{c}{$\%$} \\
\hline Kayu & 16 & 53.3 \\
Besi & 7 & 23.3 \\
Kayu dan besi & 1 & 3.3 \\
Gipsum & 6 & 20.3 \\
Total & 30 & 100.0 \\
\hline
\end{tabular}

Dalam memperoleh kesempatan kerja pada dasarnya diperlukan keahlian dan keterampilan. Secara jelas ditunjukkan bahwa tidak ada peranan sumber-sumber resmi pendidikan atau pelatihan yang memberikan keterampilan bagi migran Madura untuk memperoleh kesempatan kerja di sektor informal. Menilik sejumlah 
pengalaman responden, baik yang membuka usaha dagang kayu maupun besi dan gipsum, mereka menyatakan bahwa keterampilan dan keahlian yang mereka miliki diperoleh dari sektor informal itu sendiri.

Artinya, training keterampilan tersebut diperoleh dari saudara atau pun teman yang telah lebih dahulu berpengalaman bekerja di sektor informal, dengan cara tinggal bersama saudara atau teman pada kurun waktu tertentu dan ikut bekerja dalam rangka latihan keterampilan. Oleh karena itu sudah menjadi hal yang biasa apabila ditemukan di lapangan, bahwa dari setiap lapak usaha migran Madura terdiri dari sejumlah orang Madura, karena di dalamnya terdiri atas pemilik usaha serta anggota keluarga dari kampung halamannya di Madura yang ikut bekerja dalam rangka untuk dilatih dan memperoleh keterampilan, untuk kemudian menggeluti usaha yang sama di sektor informal.

\section{Modal Usaha}

Modal yang diperlukan untuk membuka usaha dagang di sektor informal ini juga tergolong kecil, berbeda dengan usaha di sektor formal yang memerlukan modal yang besar. Sethuraman (1996) dalam tulisannnya memberikan penekanan rendahnya persyaratan modal untuk menciptakan lapangan kerja di sektor informal. Modal yang dibutuhkan jauh lebih kecil dari pada di sektor formal. Sebagian besar usaha di sektor informal di kota dijalankan oleh seorang saja, tanpa ada pekerja sambilan.

Hampir seluruh migran Madura di Kota Bogor menggantungkan modal usahanya dari tabungan sendiri atau meminjam modal dari teman atau keluarga. Kegiatan usaha sektor informal migran Madura ini merupakan salah satu gambaran kegiatan ekonomi berskala kecil yang ada di kota, yang merupakan manifestasi situasi pertumbuhan kesempatan kerja di negara berkembang yang tujuannya adalah untuk memperoleh kesempatan kerja.

Dalam mengawali usaha dagang besi bekas, Pak Ma'ruf (45 tahun) memerlukan modal sebesar sepuluh juta rupiah. Modal tersebut hanya dijadikan sebagai dasar awal untuk membuka usaha, yaitu untuk menyewa lahan, membeli bahan baku serta sejumlah peralatan. Selebihnya hanya memerlukan modal keberanian. Modal awal ini merupakan hasil penjualan tabungan perhiasan milik isterinya.

Kekurangan lainnya ia peroleh dari pinjaman saudaranya yang berada di Bogor. Pada tahun 2009, biaya sewa lahan untuk membuka lapak sebesar lima juta rupiah per tahun. Lapak tersebut terdiri dari tempat penyimpanan bahan baku serta sebuah ruangan sederhana yang dijadikan sebagai rumah tinggal. Salah satu upaya yang ia lakukan untuk meringankan biaya sewa lahan adalah dengan mengajak teman Madura lainnya untuk tinggal di samping lapak usahanya, dengan demikian biaya sewa tersebut dapat dibagi dua sehingga biaya sewa yang dibayarkan lebih murah Data yang menyajikan jumlah responden berdasarkan Jenis Usaha dan Modal Usaha terdapat dalam Tabel 2.

Menilik pengalaman usaha Pak Ma'ruf yang telah diuraikan di atas, bahwa modal awal untuk membuka usaha ia peroleh dari dana pribadi dan juga pinjaman dari saudaranya. Hal ini juga seragam dengan pengalaman dari responden lainnya. Hal ini dapat tergambar dari Tabel 3 yang menyajikan data tersebut berdasarkan sumber modal.

Tabel 2. Jumlah dan Persentase Responden menurut Jenis Usaha dan Modal Usaha Dagang di Sektor Informal, Kecamatan Tanah Sareal, Kota Bogor 2012

\begin{tabular}{|c|c|c|c|c|c|c|c|c|c|c|}
\hline \multirow{3}{*}{$\begin{array}{c}\text { Modal } \\
\text { awal }\end{array}$} & \multicolumn{8}{|c|}{ Jenis Usaha } & \multirow{2}{*}{\multicolumn{2}{|c|}{ Total }} \\
\hline & \multicolumn{2}{|c|}{ Kayu } & \multicolumn{2}{|c|}{ Besi } & \multicolumn{2}{|c|}{$\begin{array}{c}\text { Kayu } \\
\text { dan } \\
\text { besi }\end{array}$} & \multicolumn{2}{|c|}{ Gipsum } & & \\
\hline & $\mathrm{n}$ & $\%$ & $\mathrm{n}$ & $\%$ & $\mathrm{n}$ & $\%$ & $\mathrm{n}$ & $\%$ & $\mathrm{n}$ & $\%$ \\
\hline$\lesseqgtr 10$ & 6 & 20.0 & 5 & 16.7 & 0 & 0 & 2 & 6.7 & 13 & 43.3 \\
\hline$\underset{\text { juta }}{\leq} 20$ & 7 & 23.3 & 0 & 0 & 0 & 0 & 4 & 13.3 & 11 & 36.7 \\
\hline $\begin{array}{l}30-50 \\
\text { juta }\end{array}$ & 3 & 10.0 & 2 & 6.7 & 0 & 0 & 0 & 0 & 5 & 16.7 \\
\hline $\begin{array}{ll}5 & 0 \\
\text { juta } & \end{array}$ & 0 & 0 & 0 & 0 & 1 & 3.3 & 0 & 0 & 1 & 3.3 \\
\hline Total & 16 & 53.3 & 7 & 23.3 & 1 & 3.3 & 6 & 20.3 & 30 & 100.0 \\
\hline
\end{tabular}

Menurut data di atas bahwa 56,7\% responden memperoleh modal dari dana pribadi dan pinjaman dari saudara, dan hanya 3,3\% yang memperoleh modal usaha dari tetangga sekitar di Bogor. Tidak ada responden yang menyebutkan pernah pinjam modal dari lembaga keuangan.

Tabel 3. Jumlah dan Persentase Responden menurut Sumber Modal Usaha, Kecamatan Tanah Sareal, Kota Bogor 2012

\begin{tabular}{lrr}
\hline \multirow{2}{*}{ Sumber Modal Usaha } & \multicolumn{2}{c}{ Jumlah Orang } \\
\cline { 2 - 3 } & $\mathrm{n}$ & \multicolumn{1}{c}{$\%$} \\
\hline Bantuan/pinjaman saudara/keluarga & 17 & 56,7 \\
Pinjaman tetangga sekitar di Bogor & 1 & 3,3 \\
Dana pribadi & 17 & 56,7 \\
Lembaga keuangan & 0 & 0 \\
Total & 35 & 116,7 \\
\hline
\end{tabular}

\section{MODAL SOSIAL MIGRAN MADURA DALAM USAHA SEKTOR INFORMAL}

\section{Jaringan Sosial}

Dalam kehidupan migran Madura selama tinggal dan bekerja di Kota Bogor, diasumsikan jaringan yang dimiliki semakin berkembang, tidak hanya bertalian dengan sesama kelompok etnisnya, tetapi juga dengan masyarakat luas yang ada di Kota Bogor maupun di luar Kota Bogor, khususnya pengembangan jaringan dalam usahanya di sektor informal yaitu perdagangan kayu dan besi bekas. Modal sosial berupa jaringan sosial mencakup jumlah orang yang dikenal dan simpul jaringan sosial.

\section{Jumlah Orang yang Dikenal}

Jaringan sosial dapat dianalisis dengan beberapa aspek, salah satunya yaitu keragaman jaringan menurut ukurannya (luas atau sempit) yang diukur dari segi jumlah orang yang di kenal selama menetap di Kota Bogor. Hasil penelitian menunjukkan bahwa jaringan sosial migran Madura di 
sektor informal tergolong sempit. Data mengenai ukuran jaringan sosial migran Madura disajikan dalam Tabel 4.

\begin{tabular}{lrr}
\hline \multirow{2}{*}{ Ukuran jaringan } & \multicolumn{3}{c}{ Jumlah Orang } \\
\cline { 2 - 4 } & $\mathrm{n}$ & \multicolumn{1}{c}{$\%$} \\
\hline Luas (158 - 320 orang) & 7 & 23,3 \\
Sempit (6 - 157 orang) & 23 & 76,7 \\
Total & 30 & 100,0 \\
\hline
\end{tabular}

Tabel 4. Jumlah dan Persentase Responden menurut Ukuran Jaringan, Kecamatan Tanah Sareal, Kota Bogor 2012

Sebesar $76,7 \%$ responden memiliki jaringan yang sempit karena jumlah orang yang dikenal antara 6 sampai 157 orang, sedangkan $23,3 \%$ responden memiliki jaringan yang luas dengan jumlah orang yang dikenal antara 158 sampai 320 orang. Semakin banyak orang yang dikenal maka akan semakin mudah bagi migran Madura untuk akses terhadap sumber-sumber bantuan, khususnya dalam dalam hal akses bahan baku dan modal, namun hasil penelitian menunjukkan jumlah orang yang dikenal oleh migran Madura hanya sedikit.

Artinya, pengenalan migran Madura di Kota Bogor hanya pada kalangan-kalangan tertentu saja. Kalangan yang terbatas tersebut memungkinkan sebagai pihak yang berperan penting dalam usaha sektor informal yang digeluti oleh migran Madura.

\section{Simpul}

Sedikitnya jumlah orang yang dikenal oleh migran Madura menyebabkan migran Madura memiliki akses yang terbatas dalam perolehan bahan baku dan modal. Berdasarkan jumlah orang yang dikenal tersebut perlu diketahui siapa yang paling berperan dan yang paling membantu mereka dalam modal usaha serta pemenuhan bahan baku. Untuk mengetahui hal tersebut dapat dilihat berdasarkan jenis simpul yang dimiliki oleh orang Madura. Dari hasil lapang diperoleh bahwa simpul yang dimiliki oleh migran Madura terdapat lima jenis simpul, yaitu: 1) Tetangga, 2) Teman Kerja, 3) Perkumpulan Madura, 4) Aparat Desa dan 5) Organisasi. Adapun di antara simpul tersebut terdapat sejumlah simpul yang paling berpengaruh terhadap pengembangan usaha di sektor informal yang dikembangkan oleh migran Madura. Dalam Tabel 5 disajikan data responden berdasarkan jumlah simpul yang dimiliki.

Tabel 5. Jumlah dan Persentase Responden menurut Jumlah Simpul, Kecamatan Tanah Sareal, Kota Bogor 2012

\begin{tabular}{lrr}
\hline \multirow{2}{*}{ Jumlah Simpul } & \multicolumn{2}{c}{ Jumlah Orang } \\
\cline { 2 - 3 } & $\mathrm{n}$ & $\%$ \\
\hline 2-3 simpul & 15 & 50.0 \\
$4-5$ simpul & 15 & 50.0 \\
Total & 30 & 100.0 \\
\hline
\end{tabular}

Dalam kaitannya dengan usaha di sektor informal yang dikembangkan oleh migran Madura, hasil penelitian ini menunjukkan bahwa simpul yang paling berperan adalah teman kerja dan perkumpulan migran Madura yang ada di Kota Bogor. Teman kerja yang terdiri dari calo bongkaran, kontraktor dan pengumpul barang bekas berperan terhadap usaha yang dijalankan khususnya dalam perolehan bahan baku, sedangkan perkumpulan migran Madura berperan dalam perolehan modal usaha.

\section{Kepercayaan}

Sebagai perantau di suatu daerah, khususnya di Kota Bogor, setiap migran Madura perlu membangun dan memiliki kepercayaan demi tercapainya suatu kehidupan yang stabil. Kepercayaan yang perlu dibangun dan dimiliki tidak hanya terhadap masyarakat setempat, tetapi juga dengan sesama migran Madura. Kepercayaan yang terpelihara dengan baik dengan sesama migran Madura dapat mendukung terbentuknya kelompok migran yang solid. Pada Tabel 6 tersaji data mengenai tingkat kepercayaan yang dimiliki oleh migran Madura.

Tabel 6. Jumlah dan Persentase Responden menurut Tingkat Kepercayaan, Kecamatan Tanah Sareal, Kota Bogor 2012

\begin{tabular}{lrr}
\hline \multirow{2}{*}{ Tingkat Kepercayaan } & \multicolumn{2}{c}{ Jumlah orang } \\
\cline { 2 - 3 } & $\mathrm{n}$ & \multicolumn{1}{c}{$\%$} \\
\hline Tinggi & 11 & 36,7 \\
Rendah & 19 & 63,3 \\
Total & 30 & 100,0 \\
\hline
\end{tabular}

Dalam Tabel 6 diketahui bahwa tingkat kepercayaan yang dimiliki oleh migran Madura tergolong rendah yakni sebesar $63,3 \%$. Hal ini terjadi karena kepercayaan yang dibangun dengan baik hanya pada salah satu sisi saja, yaitu dengan sesama migran Madura, sedangkan terhadap masyarakat setempat kurang terbangun dengan baik. Tingkat kepercayaan sosial tersebut berpengaruh terhadap keberlanjutan dan kemajuan usaha yang dikembangkan oleh migran Madura Analisis tingkat kepercayaan dengan sesama Madura dan terhadap masyarakat setempat dibahas sebagai berikut.

\section{Kepercayaan terhadap Sesama Migran Madura}

Kepercayaan yang dimiliki terhadap sesama migran Madura tergolong tinggi. Perasaan yang dimiliki sebagai sesama migran/perantau merupakan salah satu hal yang menjadikan hubungan sesama migran menjadi erat. Keeratan hubungan tersebut terbentuk karena didukung oleh komunikasi dan pertemuan yang terus-menerus antar migran Madura. Pertemuan rutin yang terselenggara dua kali dalam seminggu yang diakomodasi oleh perkumpulan migran Madura se-Bogor, merupakan sarana yang mempertemukan migran Madura satu dengan yang lain, sehingga mempermudah untuk saling berinteraksi. Data yang menunjukkan tingkat kepercayaan terhadap sesama migran Madura disajikan dalam Tabel 7.

\section{Kepercayaan terhadap Sesama Migran Madura}

Kepercayaan yang dimiliki terhadap sesama migran Madura tergolong tinggi. Perasaan yang dimiliki sebagai sesama migran/perantau merupakan salah satu hal yang menjadikan hubungan sesama migran menjadi erat. Keeratan hubungan tersebut terbentuk karena didukung 
oleh komunikasi dan pertemuan yang terus-menerus antar migran Madura. Pertemuan rutin yang terselenggara dua kali dalam seminggu yang diakomodasi oleh perkumpulan migran Madura se-Bogor, merupakan sarana yang mempertemukan migran Madura satu dengan yang lain, sehingga mempermudah untuk saling berinteraksi. Data yang menunjukkan tingkat kepercayaan terhadap sesama migran Madura disajikan dalam Tabel 7.

Tabel 7. Jumlah dan Persentase Responden menurut Tingkat Kepercayaan terhadap Sesama Migran Madura, Kecamatan Tanah Sareal, Kota Bogor 2012

\begin{tabular}{lrr}
\hline \multicolumn{1}{c}{ Tingkat Keper- } & \multicolumn{2}{c}{ Jumlah orang } \\
\cline { 2 - 3 } & $\mathrm{n}$ & $\%$ \\
\hline Tinggi & 29 & 96,7 \\
Rendah & 1 & 3,3 \\
Total & 30 & 100,0 \\
\hline
\end{tabular}

Data yang tersaji dalam Tabel 10 menunjukkan sebesar 96,7\% tingkat kepercaayan denan sesama migran Madura tergolong tinggi, namun terdapat $3,3 \%$ atau satu orang responden yang memiliki kepercayaan yang rendah terhadap migran Madura lainnya.

\section{Kepercayaan terhadap Masyarakat Setempat}

Hasil penelitian ini menunjukkan bahwa tingkat kepercayaan migran Madura terhadap masyarakat setempat tergolong rendah. Tingkat kepercayaan yang dimiliki oleh migran Madura terhadap masyarakat setempat tergolong rendah dikarenakan hubungan komunikasi dan interaksi dengan masyarakat sekitar juga rendah. Interaksi ini dapat dilihat dari seberapa besar responden mengikuti kegiatan bersama dengan masyarakat, di antaranya adalah kegiatan ronda, kerja bakti desa dan kegiatan pengajian. Data mengenai tingkat kepercayaan tersebut disajikan dalam Tabel 8.

Tabel 8. Jumlah dan Persentase Responden menurut Tingkat Kepercayaan terhadap Masyarakat Setempat Kecamatan Tanah Sareal, Kota Bogor 2012

\begin{tabular}{lrr}
\hline \multirow{2}{*}{ Tingkat Kepercayaan } & \multicolumn{3}{c}{ Jumlah orang } \\
\cline { 2 - 4 } & $\mathrm{n}$ & $\%$ \\
\hline Tinggi & 2 & 6,7 \\
Rendah & 28 & 93,3 \\
Total & 30 & 100,0 \\
\hline
\end{tabular}

Berdasarkan data dalam Tabel 8 sebesar 93,3\% responden tidak aktif dalam kegiatan tersebut. Sebagian besar menyatakan tidak bisa ikut dalam kegiatan-kegiatan tersebut adalah karena sibuk bekerja, sehingga tidak sempat berpartisipasi dalam kegiatan yang terdapat di masyarakat sekitar.

\section{Norma}

Berdasarkan hasil wawancara yang diperoleh dengan sejumlah responden, terdapat aturan yang harus ditaati oleh sesama migran Madura yang berdagang kayu dan besi bekas serta gipsum. Aturan-aturan tersebut adalah:
1. Dalam situasi berdagang, apabila ada konsumen yang sedang bertransaksi di lapak milik migran Madura lain, maka pedagang yang lain tidak boleh mempersuasi konsumen tersebut untuk membeli di lapak usahanya.

2. Dalam proses negosiasi proyek lelang bongkaran, apabila seorang migran Madura sudah menetapkan harga lelang, maka migran madura yang lain tidak boleh menawar dengan harga yang lebih tinggi.

\section{Perkembangan Usaha di Sektor Informal}

Usaha dagang di sektor informal meliputi jenis dagang kayu bekas, besi bekas dan gipsum merupakan pekerjaan utama migran Madura di Kota Bogor yang terdapat di Kecamatan Tanah Sareal. Dengan modal dan keterampilan yang terbatas, usaha ini dapat berkembang dengan baik di kalangan migran Madura dan terus diturunkan kepada migran Madura lainnya yang menyusul bermigrasi ke Bogor, sehingga mata pencaharian ini dapat menjadi pembeda antara migran Madura dengan migran yang berasal dari daerah lain. Modal sosial berpengaruh terhadap keberlanjutan dan kemajuan usaha yang dikembangkan oleh migran Madura di sektor informal.

Selain itu, kemajuan dalam usaha sektor informal dapat ditilik berdasarkan dua hal, yaitu kemampuan migran Madura dalam memanfaatkan simpul jaringan dan karakteristik migran, dalam hal ini karakteristik tersebut yaitu status perkawinan. Migran Madura yang kurang terampil memanfaatkan simpul jaringan, khususnya simpul perkumpulan migran Madura usahanya berkembang kurang maksimal, karena dalam pergaulannya tidak menjlin hubungan yang erat dengan sesama Madura, sehingga ketika mengalami kesulitan dalam hal modal tidak mendapatkan bantuan. Demikian juga dengan migran madura yang berstatus janda. Status perkawinan tersebut berpengaruh terhadap usaha yang ia jalankan. Keterampilan wirausaha antara migran laki-laki dengan migran perempuan yang berstatus janda terdapat perbedaan yang cukup berarti. Jika dibandingkan dengan usaha yang dikembangkan oleh migran yang berstatus menikah, usaha yang dijalankan migran berstatus janda kurang berkembang dengan baik. Hal ini dapat dilihat dari produksi harian yang dihasilkan setiap hari.

\section{DIASPORA MADURA}

Diaspora tidak hanya memberikan gambaran tentang penyebaran suatu masyarakat ke daerah lain yang keluar dari daerah asalnya, tetapi menunjukkan bagaimana masyarakat tersebut mempertahankan jati dirinya di tengah budaya mayoritas yang terdapat di daerah tujuan migrasi. Ciri identik diaspora Madura adalah kemampuannya memanfaatkan peluang ekonomi yang tidak tersentuh oleh masyarakat lain. Sesuatu yang bagi masyarakat umum dipandang tidak berguna, menurut migran Madura sesuatu tersebut dapat menjadi komoditas usaha yang penting . Terdapat sejumlah catatan penelitian yang menunjukkan kegiatan ekonomi migran Madura di berbagai daerah seperti di Surabaya, Kalimantan, Sumbawa dan juga di Bogor yang memperlihatkan bagaimana pekerjaan yang digeluti oleh migran Madura dapat menjadi ciri khas etnis Madura dan mampu menguasai sektor usaha tersebut dan berkembang pesat dalam lingkaran migran Madura.

Keberadaan orang Madura sebagai migran di beberapa 
daerah di Indonesia termasuk migran Madura yang mengembangkan usaha sektor informal di Kota Bogor, memiliki cara yang berbeda untuk mempertahankan eksistensinya sebagai orang Madura. Jenis usaha yang dikerjakan tidak hanya dipandang sebagai pekerjaan atau sumber nafkah, tetapi juga menjadi penanda atau identitas sebaga migran Madura. Diaspora Madura tidak hanya diwujudkan dari budayanya sebagai salah satu etnis yang memiliki mobilitas yang tinggi yang tersebar di sejumlah daerah, tetapi juga diwujudkan dari kemampuannya dalam membentuk dan mempertahankan eksistensinya sebagai orang Madura dimana pun berada. Dengan kemampuannya menangkap peluang ekonomi, migran Madura mampu bertahan dan menjadikan usahanya sebagai identitas etnisnya. Dalam hal ini, peran perkumpulan migran Madura merupakan pengikat solidaritas yang kuat antar migran Madura sehingga menjadi kelompok etnis yang solid. Solidaritas yang kuat dilandasi oleh kepercayaan yang tinggi antara migran Madura satu dengan migran Madura lainnya. Kepercayaan yang tinggi terhadap satu kelompok etnisnya selama tinggal di daerah perantauan dapat mewujudkan kelompok etnis yang kompak.

\section{SIMPULAN DAN SARAN}

\section{Simpulan}

1. Hubungan yang kuat yang berbasiskan hubungan persaudaraan, pertemanan dan pertetanggaan yang dimiliki oleh orang Madura merupakan faktor penting berlangsungnya migrasi berantai. Orang Madura yang telah lebih dahulu bermigrasi ke Bogor menjadi saluran bagi kerabatnya yang masih tinggal di kampung halaman untuk turut bermigrasi ke Kota Bogor. Dalam hal ini, orang Madura yang telah lebih dahulu ke Bogor menjadi sumber informasi bagi orang Madura lainnya. Budaya toron (pulang kampung) merupakan momentum yang memungkinkan bagi migran Madura untuk mengajak kerabatnya ikut bermigrasi ke Bogor.

2. Usaha sektor informal yang digeluti oleh migran Madura yaitu berdagang kayu bekas, besi bekas, dan gipsum. Sebagai kegiatan ekonomi skala kecil, modal yang diperlukan tergolong rendah dengan modal awal sebesar $\leq 10$ juta rupiah. Modal tersebut diperoleh dari saudara dan tabungan pribadi. Keterampilan yang dimiliki untuk mengembangakn usaha tersebut merupakan hasil belajar ketika ikut tinggal bersama saudaranya yang berjualan barang bekas.

3. Ditinjau dari jumlah orang yang dikenal selama tinggal di Bogor, jaringan yang dimiliki migran Madura tergolong sempit yakni 6-157 orang. Berdasarkan jumlah orang yang dikenal tersebut terdapat 5 simpul yang dimiliki migran Madura. Dalam usaha tersebut, simpul yang paling berperan adalah teman kerja dan perkumpulan migran Madura. Teman kerja terdiri dari calo bongkaran, kontraktor dan pengumpul barang bekas berperan dalam perolehan bahan baku, sedangkan perkumpulan Madura berperan bagi perolehan modal. Kepercayaan yang dimiliki migran Madura tergolong rendah, karena kepercayaan yang dibangun dengan kuat hanya dengan sesama migran Madura, sedangkan dengan masyarakat sekitar kepercayaan yang dibangun tergolong lemah. Dalam menjalankan usaha sektor informal yang digeluti oleh orang Madura, aturan yang mengikat di antara migran
Madura tersebut adalah sikap saling menghargai usaha yang dimiliki oleh orang Madura lainnya. Ketidaktataan terhadap aturan tersebut dapat menimbulkan konflik dan memungkinkan memudarnya ikatan yang solid antar migran Madura.

\section{Saran}

Hasil penelitian ini menunjukkan bahwa modal sosial memiliki peranan penting dalam kegiatan ekonomi sektor informal suatu kelompok, dalam kasus ini yaitu kelompok migran Madura di Kota Bogor. Keterbatasan migran Madura dalam modal finansial dan modal manusia dapat ditopang oleh modal sosial yang berkembang dalam kehidupan mereka, sehingga usaha dagang di sektor informal perdagangan barang bekas didominasi oleh orang Madura. Oleh karena itu penulis memberikan saran kepada:

1. Penentu kebijakan. Perlu diketahui bahwa modal finansial dan modal manusia tidak dapat menjadi ukuran utama untuk menilai perkembangan ekonomi, melainkan terdapat modal lain yaitu modal sosial yang berkembang di masyarakat yang mampu mendorong suatu kelompok masyarakat untuk bertindak mandiri secara ekonomi tanpa menggantungkan sepenuhnya kepada pemerintah.

2. Masyarakat umum. Perlu disadari bersama bahwa perkembangan zaman yang semakin canggih memicu masyarakat untuk hidup individualis, sehingga nilainilai gotong royong semakin memudar. Oleh karena itu dihimbau untuk tetap mempertahankan nilai-nilai kehidupan dan berupaya untuk tetap mempertahankan hubungan sosial yang dapat menjadi penopang ketika menghadapi kesulitan.

\section{DAFTAR PUSTAKA}

Ahmadi S. 2003. Studi tentang kehidupan ekonomi orang Madura di Sumbawa: analisis kapital sosial [tesis]. [Internet]. [20 Oktober 2011]. Dapat diunduh dari http://www.digilib.ui.ac.id/file?file=pdf/ abstrak-73084.pdf.

Coleman J. 1988. Social capital in the creation of human capital. The American Journal of Sociology, Vol. 94. [Internet]. [23 Mei 2012]. Dapat diunduh dari www. jsotr.org/about/terms.html.

Fukuyama F. 1999. Social capital, civil society and development. The American Prospect. Vol. 22, No.1. 2001. [Internet]. [23 Mei 2012]. Dapat diunduh dari www.imf.org/external/pubs/ft/.../wp0074.pdf.

Goldscheider C. 1985. Populasi, modernisasi, dan struktur sosial. Jakarta [ID]: Rajawali.

Hariyono P. 2007. Sosiologi kota untuk arsitek. Jakarta [ID]: Bumi Aksara.

Holmes R, Dahan HM, Ashari H. 2005. A guide research in the social sciences. Selangor: Prentice Hall.

Jonge HD. 1989. Madura dalam empat zaman: pedagang, perkembangan ekonomi, dan islam. Jakarta [ID]: Gramedia. 
Kuntowijoyo. 2002. Perubahan sosial dalam masyarakat agraris madura 1850-1940.Jogjakarta [ID]: Mata Bangsa.

Lee ES. 1984. Suatu teori migrasi. Penerjemah Hans Daeng. Yogyakarta: Pusat Penelitian Kependudukan UGM.

Lawang RMZ. 2005. Kapital Sosial. Jakarta [ID]: UI Press.

Mantra IB. 1992. Pola dan arah migrasi penduduk antarpropinsi di Indonesia tahun 1990. [Makalah Seminar]. [Internet]. [16 November 2011]. Yogyakarta [ID]: Universitas Gajah Mada. Dapat diunduh dari http://i-lib.ugm.ac.id/jurnal/jurnal. php?jrnlId=329.

Noer KU. 2008. Perempuan dan migrasi (studi mengenai migrasi individual perempuan madura di Kabupaten Bekasi. [Internet]. [21 Oktober 2011]. Dapat diunduh dari http://umamnoer.com/index.php?option=com content\&view=article\&id=16:perempuan-danmigrasi\&catid $=4$ : catatan-khusus \&Itemid $=8$.

Putnam RD. 1993. The prosperous community: social capital and public life. The American Prospect no.13. 1993. [Internet]. [23 Mei 2012]. Dapat diunduh dari http://xroads.virginia.edu/ HYPER/ DETOC/assoc/13putn.html.

Putnam RD. 1995. Bowling alone: america's declining social capital. Journal of Democracy. Vol. 6, 1995. [Internet]. [23 Mei 2012]. Dapat diunduh dari http://xroads.virginia.edu/ HYPER/DETOC/assoc/ bowling.html.

Rusli S. 1996. Pengantar ilmu kependudukan. Jakarta [ID]. LP3ES.

Sethuraman SV. 1996. Sektor informal di negara berkembang. Di dalam Manning $\mathrm{C}$ dan Effendi $\mathrm{TN}$, editor. Urbanisasi, Pengangguran, dan Sektor Informal di Kota. Jakarta [ID]. Gramedia.

Suhanadji. 1998. Migrasi dan adaptasi orang madura di Surabaya (kajian perilaku ekonomi migran madura di keluraahan Sidotopo, Kecamatan Semampir, Kotamadya Surabaya). [tesis]. [Internet]. [30 September 2011]. Jakarta [ID]: Universitas Indonesia. Dapat diunduh dari http://digilib.ui.ac.id/opac/themes/libri2/detail. jsp?id=77600\&lokasi=lokal.

Warsono. 1992. Strategi adaptif migran madura di Surabaya khususnya bagi golongan kenek. [tesis]. [Internet]. [16 November 2011]. Jakarta [ID]: Universitas Indonesia. Dapat diunduh dari http:// eprints.lib.ui.ac.id/12757/1/81906\%2DStrategi\%20 adaptif\%2DTOC\%20(T9624).pdf.

www.kotabogor.go.id. Diakses pada 15 September 2012. 